\title{
BIOPRODUCTION OF $\gamma$-POLY(GLUTAMIC ACID) USING FEATHER HYDROLYSATE AS A FERMENTATION SUBSTRATE
}

\author{
Müslüm ALTUN \\ Adıyaman University, Department of Material Engineering, Adiyaman, TURKEY \\ ORCID ID: orcid.org/0000-0003-2697-7370, e-mail: muslumaltun@hotmail.com
}

Cite this article as:

Altun M. 2019. Bioproduction of $\gamma$-Poly(glutamic acid) using feather hydrolysate as a fermentation substrate. Trakya Univ J Nat Sci, 20(1): 27-34, DOI: $10.23902 /$ trkjnat.448851

Received: 29 July 2018, Accepted: 04 March 2019, Online First: 07 March 2019, Published: 15 April 2019

\begin{abstract}
Polyglutamic acid (PGA) is water-soluble and biodegradable polymer with high production cost. For feasible PGA production, feather hydrolysate $(\mathrm{FH})$ was used as fermentation substrate. $30 \mathrm{~L}$ fermentation of native feather was realized to obtain keratinase enzyme using Streptomyces pactum DSM 40530. Fermentation broth was concentrated by cross-flow filtration where the enzyme activity increased by 8.75 -fold and $8 \times 10^{3} \mathrm{UL}^{-1} \mathrm{~d}^{-1}$ of enzyme activity was the optimum for achieving $75 \%$ degradation per gram of feather. $40 \mathrm{~g} / \mathrm{L}$ of $\mathrm{FH}$ was used with different media compositions to produce PGA using Bacillus licheniformis $9945 \mathrm{a}$. Among four different cultivation where L-glutamate, tri-sodium citrate and glycerol were used as the constituents of Medium E, highest yields of $\gamma$-PGA and cell dry matter (CDM) were obtained from cultivation-1, at 5.4 \pm 0.4 and $8.6 \pm 0.5 \mathrm{~g} / \mathrm{L}$, respectively, despite the culture media did not contain glutamic acid. In cultivation-2, which was not only missing glutamate but also citrate, the $\gamma$-PGA and CDM yielded $3.2 \pm 0.2$ and $7.8 \pm 0.4 \mathrm{~g} / \mathrm{L}$, respectively whereas it was only $1.9 \pm 0.2$ and $4.2+0.4 \mathrm{~g} / \mathrm{L}$ when $\mathrm{FH}$ was used as the sole substrate in cultivation-3. When cultivation-4 was adopted where only glycerol was missing, the $\gamma$-PGA and CDM yields slightly increased to $2.3 \pm 0.2$ and $5.5 \pm 0.3 \mathrm{~g} / \mathrm{L}$, respectively. This is the first study that achieved the production of $\gamma$-PGA from FH.
\end{abstract}

Key words: $\gamma$-Poly(glutamic acid), $\gamma$-PGA, feather hydrolysate, keratinolytic activity, feather.

Özet: Poliglutamik asit (PGA) yüksek üretim maliyeti olan, suda çözünen ve biyobozunabilir bir polimerdir. Bu çalışmada, fizıbıl PGA üretimi için tavuk tüyü hidrolizatları (TH) fermantasyon substratı olarak kullanılmıştır. Keratinaz enzimi eldesi için, Streptomyces pactum DSM 40530 ile doğal tavuk tüyleri fermente (30L) edilmiştir. Fermantasyon çözeltisindeki enzim aktivitesi, çapraz akışlı filtrasyon ünitesi kullanılarak 8,75 kat deriştirilmiştir. Enzim aktivitesi $\left(8 \times 10^{3} \mathrm{UL}^{-1}\right.$ gün $\left.^{-1}\right)$, gram tavuk tüyü başına \%75'lik bozunma için optimum değer olarak belirlenmiştir. PGA üretimi için Bacillus licheniformis 9945a kullanılmış ve 40g/L TH kullanılarak farklı kompozisyonlarda besiyeri çözeltileri hazırlanmıştır. Besiyeri-E bileşenleri olan Lglutamat, sodyum sitrat ve gliserol kullanılarak dört farklı kompozisyonda besiyeri hazırlanmıştır. Bunlar arasında en fazla

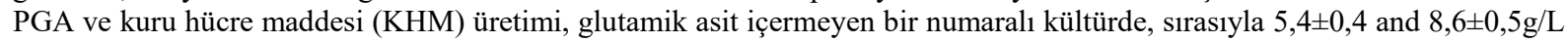
olarak gerçekleşmiştir. Glutamik asitin yanı sıra sitrik asitin de olmadığı iki numaralı kültürde PGA ve KHM değerleri sırasıyla $3,2 \pm 0,2$ ve 7,8 $\pm 0,4 \mathrm{~g} / \mathrm{L}$ olurken, sadece TH'nin substrat olarak kullanıldığ 1 üç numaralı kültürde yalnızca $1,9 \pm 0,2$ ve 4,2+0,4g/L değerleri elde edilmiştir. Sadece gliserolün kullanılmadığı dört numaralı kültürde ise PGA ve KHM değerleri bir miktar yükselmiş ve sırasıyla 2,3 $\pm 0,2$ ve $5,5 \pm 0,3 \mathrm{~g} / \mathrm{L}$ değerlerini almıştır. Yapılan çalışma PGA üretiminin TH kullanılarak yapıldığı İlk çalışma olmuştur.

\section{Introduction}

Polyglutamic acid (PGA) is a biodegradable, protease-resistant, non-immunogenic and unusual anionic homopolyamide that is made of D- and Lglutamic acid units with nylon-like properties upon esterification of its carboxyl side chains. PGA is attracting attention due to its multi-functionality in numerous fields including wastewater treatment, medicine, food industry, cosmetics, agriculture and some special applications of gene delivery, antibacterial activity, inhibition of virus, sensors and treatment of xerostomi (dry mouth) (Ben-Zur \& Goldman 2007, Wang et al. 2008, Kubota et al. 1995, Kurosaki et al.
2009, Inbaraj et al. 2011, Ogata et al. 2009, Uotani et al. 2012). PGA can be divided into two isforms, $\alpha$-PGA and $\gamma$-PGA, depending on the attachment of the carboxy group. $\gamma$-PGA has been produced extensively using especially Bacillus species. It can either be in the form of only L-glutamic acid residues or D-glutamic acid residues. $\gamma$-PGA is a ribosome-independent synthesized protein since glutamate is polymerized inside the cell via the $\gamma$-amide linkages which results in eliminating the inhibiting effect of substances like chloramphenicol during protein translation. $\gamma$-PGA can be in the watersoluble free acid or salt form with a variety of cations 
such as $\mathrm{Na}^{+}, \mathrm{Mg}^{2+}, \mathrm{K}^{+}, \mathrm{NH}^{4+}$ or $\mathrm{Ca}^{2+}$ where the latter is completely soluble (Ashiuchi et al. 2006, Ogunleye et al. 2015). A big obstacle for $\gamma$-PGA production and application is its relatively high cost and low productivity which is also recognized for any biotechnologically produced industrial good. Apart from some biopolymers such as polylactic acid and cellulose, many others suffer from high production cost for a successful commercialization (Bajaj \& Singhal 2011). One option for cost-efficient production of biopolymers is valorization of renewable resources or wastes, including byproducts of agriculture, horticulture and food industry as low-cost substrates. Among others, feathers could be promising due to their production in large amounts as a waste by-product at poultry processing plants throughout the world. Feathers are composed of over $90 \%$ keratin, which is a fibrous and insoluble protein. Highly cross-linked nature of feather with disulfide and other bonds hinders their degradation by commonly known proteolytic enzymes like trypsin, pepsin and papain. Despite the recalcitrance structure of keratin, it can be degraded efficiently by certain bacteria by means of their keratinolytic proteases or keratinases. While established methods such as steam pressure cooking requires high-energy input and the resulted feather meal is deficient in methionine and histidine which restricts to be used as animal feed, hydrolysis of keratinous waste by keratinolytic activity represents an attractive method for its bioconversion and improved nutritional value (Kornillowicz-Kowalska \& Bohacz 2011).

Growth substrate costs often constitute the major part of the production cost for microorganisms and bioproducts. Nitrogen sources are usually the most expensive medium compenent. Peptones, as organic nitrogen sources are one of the most important elements for cultivation of microorganisms. On the other hand, these protein hydrolysates (peptones) could be produced from feather keratin and known as feather hydrolysates (FH) (Vasileva-Tonkova et al. 2007). This study was performed to demonstrate and evaluate for the first time the use of enzymatically produced $\mathrm{FH}$ for the production $\gamma$-PGA using biotechnological approaches. In the first step, the native goose feather was used as the sole carbon and nitrogen source to produce keratinolytic enzyme via 30-L fermentation. Then, the lyophilized crude enzyme was utilized to degrade feather to produce $\mathrm{FH}$, and lastly the generated FH was used as a cheap and renewable medium to evaluate the production of $\gamma$-PGA in combination with different media compositions.

\section{Materials and Methods}

\section{Bacterial strains and cultivation conditions}

The bacterial strain used for keratinolytic enzyme production, Streptomyces pactum DSM 40530, was grown from spores in GYM medium [glucose $(4.0 \mathrm{~g} / \mathrm{L})$, yeast extract $(4.0 \mathrm{~g} / \mathrm{L})$, malt extract $(10.0 \mathrm{~g} / \mathrm{L})]$. Agar $(12.0 \mathrm{~g} / \mathrm{L})$ and $\mathrm{CaCO}_{3}(2.0 \mathrm{~g} / \mathrm{L})$ were added for solid medium. The flasks were incubated on a Pilotshake RC-
4/6-W horizontal shaker (Kühner AG, Birsfelden, Switzerland) at $30^{\circ} \mathrm{C}, 130 \mathrm{rpm}$ and 24 -h cultures were used as inocula $(5 \%, \mathrm{v} / \mathrm{v})$. The medium used for keratinolytic enzyme production contained the following (in g/L): goose feather (5.0), $\mathrm{K}_{2} \mathrm{HPO}_{4}(0.1), \mathrm{KH}_{2} \mathrm{PO}_{4}$ (0.3), $\mathrm{MgSO}_{4} \cdot 7 \mathrm{H}_{2} \mathrm{O}(0.3)$, and $10 \mathrm{~mL}$ of trace element solution containing (in $\mathrm{mg} / \mathrm{L}$ ) $\mathrm{CaCl}_{2}$ (3969.5), $\mathrm{Fe}$ (III) citrate (979.8), $\mathrm{MnSO}_{4}$ (219.7), $\mathrm{ZnCl}_{2}$ (95.4), $\mathrm{CuSO}_{4}$ (25.5), $\mathrm{CoCl}_{2}$ (40.5), $\mathrm{Na}_{2} \mathrm{MoO}_{4}$ (24.2) and $\mathrm{Na}_{2} \mathrm{~B}_{4} \mathrm{O}_{7}$ (99.2). S. pactum was cultivated for 4 days at $\mathrm{pH} 7$ and $30^{\circ} \mathrm{C}$ after the medium was autoclaved at $121^{\circ} \mathrm{C}$ for 20 minutes. Whole goose feathers were obtained from a local company and were used without any pre-treatment procedure for the enzyme production process (Böckle \& Müller 1997).

The $\gamma$-PGA producer Bacillus licheniformis 9945a was grown in Standard I medium or Medium E with $15 \mathrm{~g} / \mathrm{L}$ agar at $37^{\circ} \mathrm{C}$ for $20 \mathrm{~h}$. Strong $\gamma$-PGA producers were selected by visual inspection for mucoid colonies by repeated (3 times) restreaking (Leonard et al. 1958). Precultures of B. licheniformis 9945 a were grown overnight in Medium $\mathrm{E}$ at $30^{\circ} \mathrm{C}$ and $130 \mathrm{rpm}$ and were used as inocula $(2 \%, \mathrm{v} / \mathrm{v})$. For flask-based $\gamma$-PGA production experiments, four different modified versions of Medium E were used with supplementation of FH. The modified media were prepared from the following compounds (in g/L); FH (40.0), L-glutamate (25.6), tri-sodium citrate dihydrate (18.7), glycerol (50.0), $\mathrm{K}_{2} \mathrm{HPO}_{4}$ (0.5), $\mathrm{MgSO}_{4} \cdot 7 \mathrm{H}_{2} \mathrm{O}(0.5), \mathrm{FeCl}_{3} \cdot 6 \mathrm{H}_{2} \mathrm{O}(0.04), \mathrm{MnSO}_{4} \cdot \mathrm{H}_{2} \mathrm{O}$ (0.1), $\mathrm{CaCl}_{2} \cdot 2 \mathrm{H}_{2} \mathrm{O}(0.2)$ and $1 \mathrm{~mL}$ of trace element solution SL-6; $\mathrm{ZnSO}_{4} \cdot 7 \mathrm{H}_{2} \mathrm{O}(0.1), \mathrm{MnCl}_{2} \cdot 4 \mathrm{H}_{2} \mathrm{O}(0.03)$, $\mathrm{H}_{3} \mathrm{BO}_{3}(0.3), \mathrm{CoCl}_{2} \cdot 6 \mathrm{H}_{2} \mathrm{O}(0.2), \mathrm{CuCl}_{2} \cdot 2 \mathrm{H}_{2} \mathrm{O}$ (0.01), $\mathrm{NiCl}_{2} \cdot 6 \mathrm{H}_{2} \mathrm{O}$ (0.02), $\mathrm{Na}_{2} \mathrm{MoO}_{4} \cdot 2 \mathrm{H}_{2} \mathrm{O}(0.03)$. For different trials, required compounds were added to $\mathrm{FH}$ solution separately after autoclaving. The $\mathrm{pH}$ of the medium was adjusted to 6.5 with $1 \mathrm{~N} \mathrm{HCI}$ or $5 \mathrm{~N} \mathrm{NaOH}$ as required, and the experiments were performed at $30^{\circ} \mathrm{C}, 130 \mathrm{rpm}$. The flow diagram of the $\gamma$-PGA production process is shown in Fig. 1. All experiments were performed in duplicate and the results are presented as the mean values of the duplicates during the course of study.

Keratinolytic enzyme production: 30 L-scale fermentation

A Biostat UD30 stainless steel reactor (B. Braun Biotech International, Melsungen, Germany) with a working volume of $30 \mathrm{~L}$ was connected to a digital control unit capable of controlling fermentation parameters such as temperature, anti-foaming, $\mathrm{pH}$, agitation, and $\mathrm{pO}_{2}$ level. Foaming was controlled either by mechanical means or by addition of antifoam agent (1\%, v/v) Struktol SB2121 (Schill \& Seilacher "Struktol" GmbH, Hamburg, Germany) as required. The UD30 fermenter containing the keratinolytic enzyme production medium as described above was autoclaved in situ at $121{ }^{\circ} \mathrm{C}$ for $20 \mathrm{~min}$. The $\mathrm{pO}_{2}$ value in the medium was kept at or above $15 \%$ saturation by controlling the agitation rate between 150 and 600rpm at an aeration rate of $0.5 \mathrm{vvm}$ (volume per volume per minute). The $\mathrm{pH}$ of the medium was held at 
$7.5 \pm 0.1$ using $4 \mathrm{~N}$ of either $\mathrm{HCl}$ or $\mathrm{NaOH}$. $10 \mathrm{~mL}$ of a 24h-old inoculum (prepared in 100-mL flasks) were added to $190 \mathrm{~mL}$ (prepared in 1L flasks) of fresh GYM medium and cultured for another $24 \mathrm{~h}$. Sabsequently, 7 inoculum flasks were combined and transferred to the bioreactor. Samples taken from the bioreactor were analyzed for soluble protein and enzyme activity assays every $24 \mathrm{~h}$. After cultivation, the biomass was separated from the broth using a CEPA type Z61 continuous centrifuge (Carl Padberg Zentrifugenbau GmbH, Lahr, Germany) and subsequently the supernatant was passed through a cross-flow filtration unit (Sartoflow, Sartorius) with a $10-\mathrm{kDa}$ molecular weight cut-off in order to increase the enzyme concentration in the retentate. Finally, the retentate was freeze-dried using a BETA 1-16 freeze-drier (Christ, Osterode, Germany) to obtain concentrated crude lyophilizate containing keratinolytic enzyme.

\section{Production of feather hydrolysates by enzymatic degradation}

Freeze-dried lyophilizate enriched in keratinases was obtained from the concentrated supernatant of the 30L fermentations where native whole feather was used as the only carbon and nitrogen source, without any further enzyme purification. A set amount of lyophilizate was used for the degradation of feather using screw-cap bottles at $50^{\circ} \mathrm{C}, \mathrm{pH} 8.0$ and $250 \mathrm{rpm}$ for $24 \mathrm{~h}$. Unlike the $30 \mathrm{~L}$ fermentations, a pre-treatment step was applied to the feathers for enzymatic feather degradation experiments. Pre-treatment of feathers was done by degreasing with a methanol-chloroform (1:1) mixture using a Soxhlett apparatus with a $30 \mathrm{~cm}$ of glass extraction filter. Whole feathers were then suspended in a solution of $10 \mathrm{mM}$ $\mathrm{Na}_{2} \mathrm{SO}_{3}$ (1g feather per $100 \mathrm{~mL}$ of solution) and autoclaved at $121^{\circ} \mathrm{C}$ for 20 minutes, followed by an extensive washing step with tap water followed by distilled water. Lastly, feathers were air-dried and stored in the laboratory at room temperature. After incubation of the feathers with lyophilizate without using buffer solution, the resulting media was centrifuged $(5000 \times \mathrm{g}$, 15 minutes) and subsequently filtered using Whatman no. 1 filter paper. After incubation, the residual feather material was washed several times with distilled water and then air-dried at $70^{\circ} \mathrm{C}$ until a constant weight was obtained. The obtained filtrate served as a source of FH and was stored at $+4{ }^{\circ} \mathrm{C}$ after autoclaving until use as the main carbon, energy and nitrogen source for $\gamma$-PGA production (Altun et al. 2018). Since the hydrolysate is highly complex and has an undefined composition, the concentration of total FH was calculated by the amount of degraded feather on weight basis. The FH solution was diluted to the desired concentration with distilled water if necessary.

\section{Enzyme activity assay}

An enzyme activity assay was adapted to determine the amount of lyophilizate necessary for hydrolyses of pre-treated feather and to ensure the standardisation of the enzyme content of the lyophilizate produced from different cultivations. For this purpose, $120 \mu \mathrm{L}$ of enzyme solution $(0.2 \mathrm{mg}$ lyophilizate $/ \mathrm{mL})$ was added to $480 \mu \mathrm{L}$ of an azocasein solution $(10 \mathrm{mg} / \mathrm{mL})$ in $100 \mathrm{mM}$ phosphate at $\mathrm{pH}$ 7.0. The mixture was incubated at $50^{\circ} \mathrm{C}$ for 30 minutes, and the reaction was stopped by adding $600 \mu \mathrm{L}$ of $10 \%(\mathrm{w} / \mathrm{v})$ trichloroacetic acid and incubating the preparation on ice for 30 minutes. The mixture was then centrifuged at $10000 \times g$ for 10 minutes at $4{ }^{\circ} \mathrm{C}$ and $800 \mu \mathrm{L}$ of the supernatant was added to $200 \mu \mathrm{L}$ of $\mathrm{NaOH}(1.8 \mathrm{M})$. One unit of enzyme activity was defined as the amount of enzyme that resulted in an increase of one unit absorbance at 440nm under the assay conditions (Thys et al. 2004).

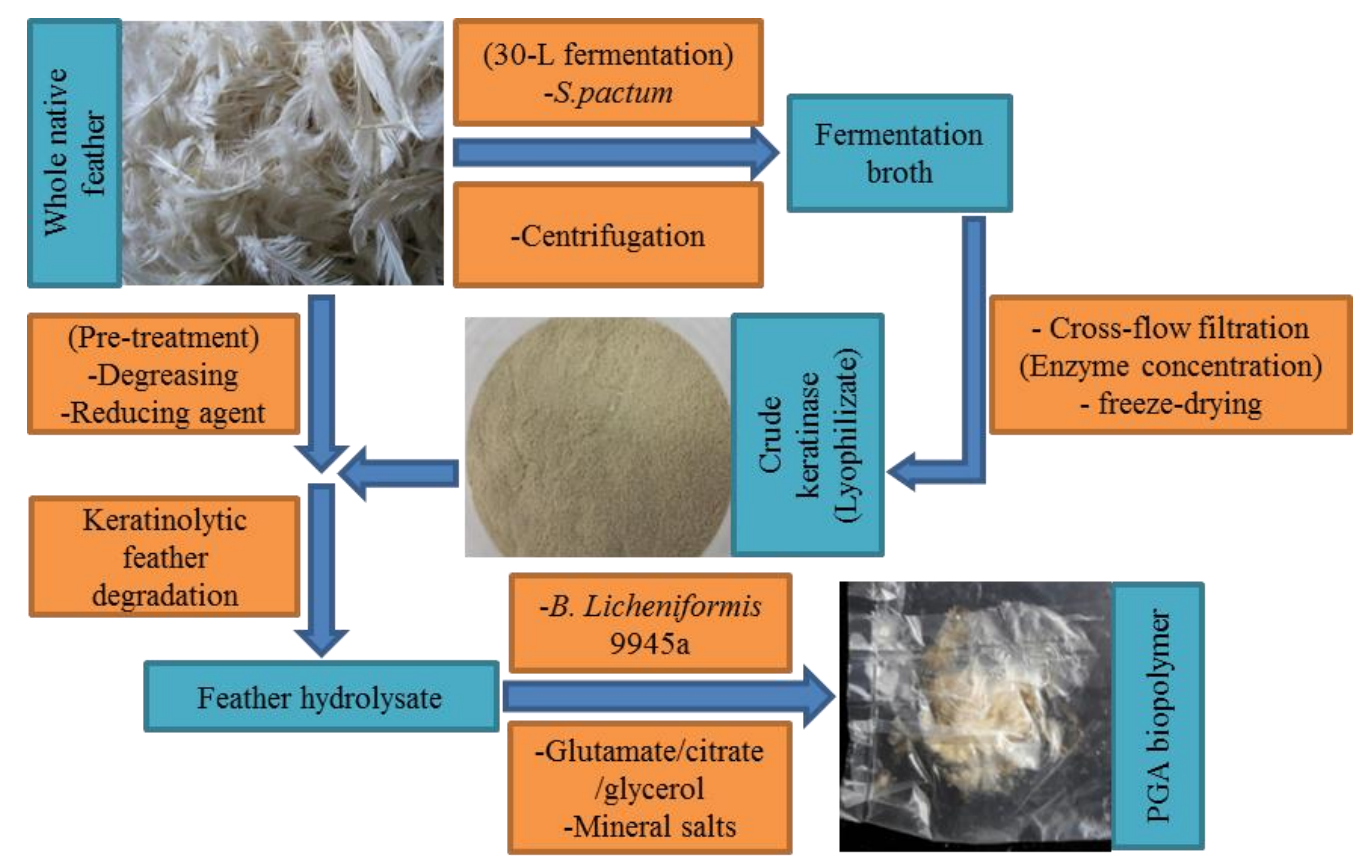

Fig. 1. The flow chart of $\gamma$-PGA production process using feather as substrate. 


\section{Production and isolation of $\gamma-P G A$}

The $\gamma$-PGA production was realized using $50 \mathrm{~mL}$ (in $250 \mathrm{~mL}$ flasks) of variations of Medium E at $30^{\circ} \mathrm{C}$ and $130 \mathrm{rpm}$ with supplementation of $40.0 \mathrm{~g} / \mathrm{L} \mathrm{FH}$ as described above. Isolation and purification of $\gamma$-PGA was done according to a previously reported method (Troy 1973). Briefly, after the cultures reached stationary phase, half of the culture medium was mixed with an equal volume of ice and blended. After the ice thawed, the cells were separated from the culture broth by centrifugation $(60$ minutes, $3000 \times g, 4^{\circ} \mathrm{C}$ ) and the resulting pellets were lyophilized after washing with distilled water for cell dry matter (CDM) calculations. The supernatant was mixed with 4 volumes of ice-cold ethanol and incubated for $24 \mathrm{~h}$ at $-20^{\circ} \mathrm{C}$. The precipitated $\gamma$-PGA was separated from the supernatant by careful decanting and dried for several hours under a stream of compressed air. The crude precipitate was dissolved in $20 \mathrm{~mL}$ of water, centrifuged to remove insoluble materials, and dialysed against 5.0L of water using dialysis membrane tubing (Spectra/Por ${ }^{\circledR}$ ) that had been boiled in $2 \% \mathrm{NaHCO}_{3}$ before use. The resultant solution was lyophilized to obtain pure $\gamma$-PGA, which was then weighed for yield calculation.

The statistical analysis of the data was performed by using SPSS Version 15.0 software (SPSS Inc., USA). Normality was assessed with the Shapiro-Wilk test and Levene's test was used for homogeneity of variances. One-way analysis of variance (ANOVA) was conducted, followed by pair-wise comparisons of each group using independent sample post hoc tukey test. Significance was designated at $\mathrm{p}<0.05$ for all data analyzed.

\section{Analytical methods}

The cell dry matter was determined by weighing the lyophilized cells. The soluble protein concentration of FH was measured by the Bradford method (Bradford 1976). The L-glutamic acid content of the FH and the amino acid constituents of the isolated $\gamma$-PGA were determined by high-performance liquid chromatography (HPLC) using a Waters B801 (300- by 4-mm) column (Aboulmagd et al. 2000, Steinle et al. 2009). Pre-column OPA derivatization was done using a Smartline Autosampler 3900 as described in the manual (Knauer GmbH, Berlin, Germany). Calibration was done with samples from a reference kit for L-glutamic acid (Kollektion AS-10 from Serva Feinbiochemica, Heidelberg, Germany). $\gamma$-PGA was hydrolyzed in $6 \mathrm{M} \mathrm{HCl}\left(100 \mu 1 / \mathrm{mg} \gamma\right.$-PGA) at $95^{\circ} \mathrm{C}$ overnight, neutralized, and lyophilized before analysis.

\section{Results and Discussion}

Keratinolytic enzyme production: $30 L$ scale fermentation

Streptomyces pactum was used for the $30 \mathrm{~L}$ fermentation for the keratinases production because it is able to use native whole feather as a carbon and nitrogen source without treatment. This eliminates the use of expensive carbon and nitrogen sources such as peptones. The fermentation process was carried out over 4 days as the highest enzyme activity and highest soluble protein content was obtained at $96 \mathrm{~h}$, when almost all of the feathers had been degraded (Fig. 2). Further cultivation of the bacteria decreased the soluble protein concentration whereas the enzyme activity did not change dramatically for another 2 days (results are not shown).

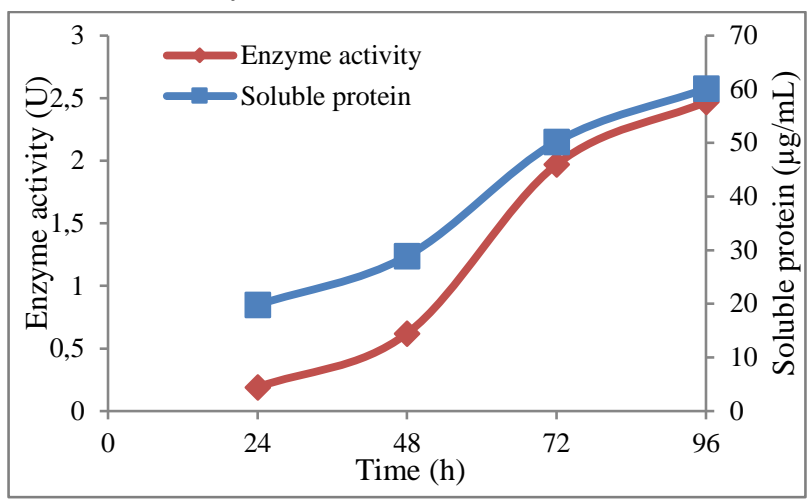

Fig. 2. Changes in enzyme activity and soluble protein during the course of the $30 \mathrm{~L}$ scale fermentation using $S$. pactum; autoclaved for $20 \mathrm{~min}$ at $121{ }^{\circ} \mathrm{C}$ before cultivation, the $\mathrm{pO}_{2}$ value was kept above $15 \%$ saturation by controlling the agitation rate between 150 and 600rpm, aeration rate: $0.5 \mathrm{vvm}, \mathrm{pH} 7.5 \pm 0.1$.

The $\mathrm{pO}_{2}$ level, which dropped below $20 \%$ during the second day of process, reached $99 \%$ saturation after $96 \mathrm{~h}$ of cultivation, proving that the bacterial metabolism had diminished. Flask experiments (data not shown) also gave similar results, but with a much lower feather degradation rate (up to $60 \%$ ), most probably because of the unfavorable aeration, mixing, and $\mathrm{pH}$ control.

A recent study used feather as a carbon and peptone source for cyanophycin biopolymer production, which is a bacterial storage polymer that is of increasing interest to the scientific community and has applications in various fields of industry (Altun et al. 2018). During this study, one of the main problems was that the lyophilized fermentation broth that contained extracellular enzyme also contained substances that had no effect on bacterial growth but lowered the feather degradation performance of keratinases. In the present study, in order to avoid these problems, following the centrifugation an additional step was adopted to wash out such substances from the fermentation broth retentate by using cross-flow filtration which resulted in concentrated crude enzyme. When the total volume of the fermentation broth retentate was decreased by a factor of 15 , the washing process increased the volumetric enzyme activity by 8.75 -fold. The enzyme activity recovery rate after cross-flow filtration was $58.3 \%$. The protein content of the permeate (below $10 \mathrm{kDa}$ in size) accounts for only $2.9 \%$ of total protein which shows efficiency of the filtrating process.

\section{Enzymatic feather hydrolysate production}

Lyophilization of the concentrated crude enzyme offered many advantages over the liquid form, such as ease of storage, handling, and preservation of enzyme activity over the course of the study (Altun et al. 2018). Since one of the goals of the study was to establish a method of producing $\gamma$-PGA in a simple, cost- and time- 
effective manner, the lyophilizate was not subjected to further processing or purification steps. Production of FH by enzymatic treatment was performed by the addition of lyophilizate containing keratinases to glass screw-cap bottles containing the required amount of pre-treated feathers. Since feather keratin is a recalcitrant material that shows resistance to proteolytic degradation because of its extensively cross-linked structure, e.g. via disulfide bonds, hydrogen bonds, and salt bridges, a single keratinolytic protease is not sufficient for complete keratine hydrolysis. Extensive cystine bridges, which are structural features of feather, prevent the enzymatic degradation of keratine (Sangali \& Brandelli 2000, Ramani et al. 2005, Kunert 1992, Böckle at al. 1995). Therefore, a reducing agent is required to disrupt disulfide bonds and make the feather material susceptible to enzymatic hydrolysis. Experiments from a previous study of our group suggested that $\mathrm{Na}_{2} \mathrm{SO}_{3}$ was the best candidate among others (cysteine, glutathione, mercaptoethanol and dithioerythritol) because of the relatively cheaper cost, non-toxcicity and efficient disulfide cleavage rate with a concentration of $10 \mathrm{mM}$. An enzyme activity of $8 \times 10^{3} \mathrm{U}$ per $\mathrm{g}^{-1} \mathrm{~L}^{-1} \mathrm{~d}^{-1}$ of feather was the optimum value for achieving up to $75 \%$ feather degradation. In both cases, further increase of $\mathrm{Na}_{2} \mathrm{SO}_{3}$ or enzyme concentration did not affect feather degradation performance dramatically. This result is in good accordance with the literature, where the best result ( $82 \%$ feather degradation) was obtained when $10 \mathrm{~g} / \mathrm{L}$ of pre-treated feather (using dithioerythritol as a reductant) was used. For optimum enzyme activity and satisfactory feather degradation rate, an incubation temperature of $50^{\circ} \mathrm{C}$ at $\mathrm{pH} 8.0$ was appropriate (Böckle $a t$ al. 1995). Using lyophilizate of the concentrated enzyme obtained by cross-flow filtration greatly increased feather degradation from $43.8 \%$ to $73.4 \%$, where the former result was obtained with the lyophilizate from unconcentrated crude enzyme at same activity. According to HPLC analysis, the FH generated by keratinase activity also contained free amino acids such as aspartic acid, serine, arginine, alanin, valine, isoleucine, leucine, lysine, methionine and glutamic acid. Among others, glutamic acid plays an important role in $\gamma$-PGA biosynthesis and had a concentration of $15 \mathrm{mg}$ per $\mathrm{g}$ FH used.

\section{Production of $\gamma$-PGA using $F H$}

$\gamma$-PGA is up to a hundred-fold more expensive than its conventional alternatives, and a reduction of the production cost seems to be the only option to solve the problem (Sung et al. 2005). In order to contribute to the cost-effective $\gamma$ PGA production, FH derived from enzymatic hydrolysis of feather was used to produce biopolymer using different media compositions as depicted in Table 1.

Bacillus licheniformis 9945a, the most widely used bacterium for $\gamma$-PGA production, was chosen as a model microorganism. As shown in Table 1, while FH, salts and micro nutrients were used in all cultivations, L-glutamate, sodium citrate and glycerol were used interchangeably in four cultivations in order to observe the effect of substrate composition on bacterial growth and $\gamma$-PGA production.
Table 1. Chemical composition of different cultivations for $\gamma$ PGA production.

\begin{tabular}{lcccc}
\hline \hline \multicolumn{1}{c}{ Substances } & Cltv & Cltv & Cltv & Cltv \\
& $\mathbf{1}$ & $\mathbf{2}$ & $\mathbf{3}$ & $\mathbf{4}$ \\
\hline \hline FH & + & + & + & + \\
L-glutamate & - & - & - & + \\
tri-sodium citrate dihydrate & + & - & - & + \\
$\begin{array}{l}\text { Glycerol } \\
\text { K2HPO4, MgSO4·7H2O, }\end{array}$ & + & + & - & - \\
FeCl3·6H2O & & & & \\
MnSO4·H2O, CaCl2·2H2O & + & + & + & + \\
SL-6 solution & & & & \\
\hline Cltv: Cultivation. & & & &
\end{tabular}

Fig. 3 represents the $\mathrm{OD}_{600}$ measurements for all cultivations. Cultivation-1 (without L-glutamate) and -2 (without L-glutamate and tri-sodium citrate dihydrate) reached the stationary phase at $60 \mathrm{~h}$ and exhibited substantial growth, whereas cultivation-3 (without Lglutamate, tri-sodium citrate dehydrate and glycerol) and -4 (without glycerol) reached stationary phase much earlier, approximately at $30 \mathrm{~h}$.

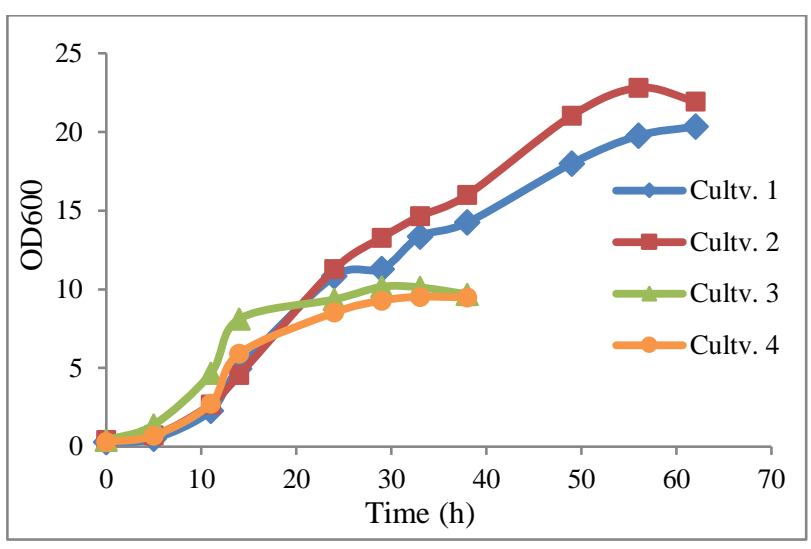

Fig. 3. Changes in $\mathrm{OD}_{600}$ values for varied culture compositions during $\gamma$-PGA production in flasks; $30^{\circ} \mathrm{C}, 130 \mathrm{rpm}$, inocula: $2 \%$ $(\mathrm{v} / \mathrm{v}), \mathrm{pH}$ 6.5, (Erlenmeyer flasks (volume $250 \mathrm{ml}$ ) contained $50 \mathrm{ml}$ of the combined media).

The $\gamma$-PGA and CDM yields of cultivations- 1 and -2 are much higher than those of cultivations -3 and -4 due to the supplementation of the culture media with glycerol (Table 2.). This result is in good accordance with the literature since glycerol is also reported to encourage PGA production in most studied strains in addition to its favorable effect on bacterial growth. Troy (1973) proposed that glycerol could stimulate polyglutamyl synthetase, which catalyses the polymerization of glutamic acid to PGA and it is also responsible for a decrease of PGA chain length, which lowers the viscosity of the culture broth and increases the uptake rate of substrates, and consequently leads to improved cell growth and PGA production.

As shown in Table 2, the highest yields of 5.4 \pm 0.4 and $8.6 \pm 0.5 \mathrm{~g} / \mathrm{L}$ were obtained from cultivation- 1 for $\gamma$-PGA and CDM, respectively, despite the culture media did not contain glutamic acid, an essential precursor for $\gamma$-PGA production. 
Table 2. $\gamma$-PGA yield $(\mathrm{g} / \mathrm{L})$ and $\mathrm{CDM}(\mathrm{g} / \mathrm{L})$ measurement of cultivations in flasks $\left(30^{\circ} \mathrm{C}, 130 \mathrm{rpm}\right.$, inocula: $2 \%(\mathrm{v} / \mathrm{v})$, $\left.\mathrm{pH} 6.5\right)$.

\begin{tabular}{|c|c|c|c|c|c|}
\hline \multicolumn{2}{|c|}{$\mathbf{C D M}^{\mathbf{a}} / \gamma-\mathbf{P G A}^{\mathbf{b}}$} & \multicolumn{2}{|c|}{ CDM } & \multicolumn{2}{|c|}{$\gamma$-PGA } \\
\hline Cultivations & Mean \pm Std. Error & Cultivations & Mean \pm Std. Error & Cultivations & Mean \pm Std. Error \\
\hline \multirow{3}{*}{ Cultv-1 } & \multirow{3}{*}{$\begin{array}{l}8.6 \pm 0.5^{\mathrm{a}} \\
5.4 \pm 0.4^{\mathrm{b}}\end{array}$} & Cultv-3 & $4.2 \pm 0.4 *$ & Cultv-2 & $3.2 \pm 0.2 *$ \\
\hline & & \multirow{2}{*}{ Cultv-4 } & \multirow{2}{*}{$5.5 \pm 0.3 *$} & Cultv-3 & $1.9 \pm 0.2 *$ \\
\hline & & & & Cultv-4 & $2.3 \pm 0.2 *$ \\
\hline \multirow{2}{*}{ Cultv-2 } & \multirow{2}{*}{$\begin{array}{l}7.8 \pm 0.4^{\mathrm{a}} \\
3.2 \pm 0.2^{\mathrm{b}}\end{array}$} & Cultv-3 & $4.2 \pm 0.4 *$ & \multirow{2}{*}{ Cultv-1 } & \multirow{2}{*}{$5.4 \pm 0.4^{*}$} \\
\hline & & Cultv-4 & $5.5 \pm 0.3 *$ & & \\
\hline \multirow{2}{*}{ Cultv-3 } & \multirow{2}{*}{$\begin{array}{l}4.2 \pm 0.4^{\mathrm{a}} \\
1.9 \pm 02^{\mathrm{b}}\end{array}$} & Cultv-1 & $8.6 \pm 0.5^{*}$ & \multirow{2}{*}{ Cultv-1 } & \multirow{2}{*}{$5.4 \pm 0.4^{*}$} \\
\hline & & Cultv-2 & $7.8 \pm 0.4^{*}$ & & \\
\hline \multirow{2}{*}{ Cultv-4 } & \multirow{2}{*}{$\begin{array}{l}5.5 \pm 0.3^{\mathrm{a}} \\
2.3 \pm 0.2^{\mathrm{b}}\end{array}$} & Cultv-1 & $8.6 \pm 0.5^{*}$ & \multirow{2}{*}{ Cultv-1 } & \multirow{2}{*}{$5.4 \pm 0.4^{*}$} \\
\hline & & Cultv-2 & $7.8 \pm 0.4 *$ & & \\
\hline
\end{tabular}

This shows that either use of FH and/or presence of citric acid could compensate absence of glutamic acid to some degree during cultivation-1 which should be elaborated with further experiments. In cultivation-2, $\gamma$ PGA yield decreased to $3.2 \pm 0.2 \mathrm{~g} / \mathrm{L}$, while CDM yield $(7.8 \pm 0.4 \mathrm{~g} / \mathrm{L})$ did not change dramatically. The sharp decrase of $\gamma$-PGA yield could be from the fact that this culture was not only missing glutamic acid but also citric acid, which is another crucial precursor and affects $\gamma$-PGA production significantly. The lowest values were obtained by cultivation-3, which was included to observe the effect of FH as the sole substrate on CDM and $\gamma$-PGA yield, without the use of glycerol and precursors. When the results of cultivation- 3 are compared with cultivation-4, it was observed that there is a slight increase in both CDM and $\gamma$-PGA yields when glutamic and citric acids were added to the culture medium though the difference was not statistically significant ( $p>0.05$ ) according to the oneway ANOVA with Tukey test. Also, a comparison of cultivations- 3 and -2 reveals the significance of glycerol, which increased CDM and $\gamma$-PGA yields by 1.9 and 1.7fold, respectively, however the latter was also not different statistically $(\mathrm{p}>0.05)$. The present results showed that the effect of glycerol on CDM yield is much higher than that on $\gamma$-PGA production and supplementation of $\mathrm{FH}$ to the medium is encouraging microbial growth rather than $\gamma$-PGA production. In all cultivations, HPLC analysis of extracted $\gamma$-PGA showed the high purity of the biopolymer.

Cromwick et al. (1996) obtained $15 \mathrm{~g} / \mathrm{L}$ of $\gamma$-PGA using B. licheniformis 9945 a and Medium E in $2 \mathrm{~L}$ batch fermentations ( $\mathrm{pH} 6.5,250 \mathrm{rpm}, 96 \mathrm{~h})$, which provides better aeration and $\mathrm{pH}$ control than that of flask-based experiments, resulting in increased polymer yield. When the effect of aeration was examined by increasing the agitation speed ( 250 to $800 \mathrm{rpm})$ and aeration rate $(0.5$ to $2.0 \mathrm{~L} / \mathrm{min}$ ) at $\mathrm{pH} 6.5$, both the $\gamma-\mathrm{PGA}$ and CDM yields increased from 2.0 to $4.0 \mathrm{~g} / \mathrm{L}$ and 6.3 to $23 \mathrm{~g} / \mathrm{L}$ in $48 \mathrm{~h}$, respectively. Although the CDM content of cultivation-1 is higher (2 to 4.3-fold) than that of the study of Cromwick et al. (1996), the $\gamma$-PGA yield is lower (4.3-fold). It is assumed that the media composition used in the present study mostly favored bacterial growth rather than $\gamma$-PGA production. Also, the lower $\gamma$-PGA yield could be attributed to the unfavorable conditions in flasks, such as inadequate aeration and lack of $\mathrm{pH}$ control. Cultivations1 and -2 were terminated once they reached stationary phase at $60 \mathrm{~h}$. It may be assumed that longer cultivation times would be required for enhanced $\gamma$-PGA production, as studies with much longer cultivation times are reported in the literature (Hoppensack et al. 2003, Goto and Kunioko 1992). Also, the media composition could be another reason, as the strain B. licheniformis $9945 \mathrm{a}$ is a strictly L-glutamic-acid-dependent microorganism, and an increase in glutamic acid concentration in the medium leads to an enhanced $\gamma$-PGA yield (Buescher \& Margaritis 2007). Qiu et al. (2017) used Jerusalem artichoke as a substrate for $\gamma$-PGA production using strain $B$. amyloliquefaciens NX-2S. After one-step fermentation without glutamate supplementation the strain produced $6.85 \pm 0.2 \mathrm{~g} / \mathrm{L}$ of $\gamma$-PGA whereas exogenous glutamate greatly affected the yield $(39.4 \pm 0.4 \mathrm{~g} / \mathrm{L})$.

On the other hand, glutamic acid is also a relatively costly material and therefore directly affects the production cost of PGA. Hence, glutamate-independent producers are more desirable for industrial $\gamma$-PGA production because of their low cost of production and ease of operation in fermentations (Cromwick et al. 1996, Du et al. 2005, Cao et al. 2011). Murao et al. (1971) reported that $B$. subtilis $5 \mathrm{E}$ did not require glutamic acid in the medium, and among the amino acids tested, proline was preferred for efficient polymer production. Proline is also one of the amino acids already exist in culture medium after enzymatic feather degradation (Jeong et al. 
2010). Moreover, mixtures of hydrolysates obtained from different keratinous sources, like wool, could also create synergy and increase nutritional value for better $\gamma$-PGA production. Using carbon sources other than glycerol, such as fructose or glucose together with supplementation of FH could also increase $\gamma$-PGA production (Ko \& Gross 1998). Thus, it could be envisaged that efficient bioconversion of FH to $\gamma$-PGA could be achieved using microorganisms that would not require glutamic and/or citric acid.

Although using keratinolytic enzymes is a promising approach for feather bioconversion, more efficient enzyme production and disulfide cleavage methods are required for economically feasible FH bioproduction. Results of the present study, which was designed as proof of principle suggest that further in-depth investigation of improved culture media compositions with supplementation of $\mathrm{FH}$ and use of glutamate and citrate independent strains could lead to an efficient $\gamma$-PGA production.

\section{References}

1. Aboulmagd, E., Oppermann-Sanio, F.B. \& Steinbüchel, A. 2000. Molecular characterization of the cyanophycin synthetase from Synechocystis sp. strain PCC 6308. Archives of Microbiology, 174: 297-306.

2. Altun, M., Wiefel, L. \& Steinbüchel, A. 2018. Cyanophycin production from feather hydrolysate using biotechnological methods. Preparative Biochemistry and Biotechnology, https://doi.org/10.1080/10826068.2018.1476881.

3. Ashiuchi, M., Shimanouchi, K., Horiuchi, T., Kamei, T. \& Misono, H. 2006. Genetically engineered poly- $\gamma$-glutamate producer from Bacillus subtilis ISW1214. Bioscience, Biotechnology, and Biochemistry, 70(7): 1794-1797.

4. Bajaj, I. \& Singhal, R. 2011. Poly(glutamic acid) - An emerging biopolymer of commercial interest. Bioresource Technology, 102: 5551-5561.

5. Ben-Zur, N. \& Goldman, D.M. 2007. $\gamma$-Poly glutamic acid: a novel peptide for skin care. Cosmetics and toiletries, 122: 65-74.

6. Böckle, B. \& Müller, R. 1997. Reduction of disulfide bonds by Streptomyces pactum during growth on chicken feathers. Applied and Environmental Microbiology, 63(2): 790-792.

7. Böckle, B., Galunsky, B. \& Müller, R. 1995. Characterization of a keratinolytic serine proteinase from Streptomyces pactum DSM 40530. Applied and Environmental Microbiology, 61(10): 3705-3710.

8. Bradford, M.M. 1976. A rapid and sensitive method for the quantitation of microgram quantities of protein utilizing the principle of protein-dye binding. Analytical Biochemistry, 72: 248-254.

9. Buescher, J.M. \& Margaritis, A.M. 2007. Microbial biosynthesis of polyglutamic acid biopolymer and applications in the biopharmaceutical, biomedical and food industries. Critical Reviews in Biotechnology, 27: 1-19.

10. Cao, M., Geng, W., Liu, L., Song, C., Xie, H., Guo, W., Jin, Y. \& Wang, S. 2011. Glutamic acid independent

\section{Conclusion}

The aim of the present study was to show the biotechnological perspective of the use of enzymatically produced $\mathrm{FH}$ as a fermentation substrate for $\gamma$-PGA production as a model process. The use of $\mathrm{FH}$ as fermentation substrate not only ensures the efficient disposal of feather, which is also classified as a hazardous material creating serious environmental problems worldwide, but also contributes to the valorization of feather with respect to its potential for future applications with biorefinery concept.

\section{Acknowledgement}

The author gratefully acknowledges the contribution made by Dr. Martin Krehenbrink from CYSAL GmbH (Münster, Germany) and Prof. Dr. Alexander Steinbüchel (Institute of Molecular Microbiology and Biotechnology, Westfalische Wilhelms-Universitat Muenster, Germany).

production of poly- $\gamma$-glutamic acid by Bacillus amyloliquefaciens LL3 and cloning of pgsBCA genes. Bioresource Technology, 102: 4251-4257.

11. Cromwick, A.M., Birrer, G.A. \& Gross, R.A. 1996. Effects of $\mathrm{pH}$ and aeration on $\gamma$-poly (glutamic acid) formation by Bacillus licheniformis in controlled batch fermentor cultures. Biotechnology and Bioengineering, 50: 222-227.

12. Du, G., Yang, G., Qu, Y., Chen, J. \& Lun, S. 2005. Effects of glycerol on the production of poly $(\gamma$-glutamic acid) by Bacillus licheniformis. Process Biochemistry, 40: 21432147.

13. Goto, A. \& Kunioka, M. 1992. Biosynthesis and Hydrolysis of Poly $(\gamma$-glutamic acid) from Bacillus subtilis IF03335. Bioscience, Biotechnology, and Biochemistry, 56(7): 1031-1035.

14. Hoppensack, A., Oppermann-Sanio, F.B. \& Steinbüchel, A. 2003. Conversion of the nitrogen content in liquid manure into biomass and polyglutamic acid by a newly isolated strain of Bacillus licheniformis. FEMS Microbiology Letters, 218: 39-45.

15. Inbaraj, B.S., Kao, T.H., Tsai, T.Y., Chiu, C.P., Kumar, R. $\&$ Chen, B.H. 2011. The synthesis and characterization of $\operatorname{poly}(\gamma$-glutamic acid $)$-coated magnetite nanoparticles and their effects on antibacterial activity and cytotoxicity. Nanotechnology, 22(7): 075101.

16. Jeong, J.H., Kim, J.N., Weeb, Y.J. \& Ryu, H.W. 2010. The statistically optimized production of poly( $\gamma$-glutamic acid) by batch fermentation of a newly isolated Bacillus subtilis RKY3. Bioresource Technology, 101: 4533-4539.

17. Ko, Y.H. \& Gross, R.A. 1998. Effects of glucose and glycerol on $\gamma$-poly(glutamic acid) formation by Bacillus licheniformis ATCC 9945a. Biotechnology and Bioengineering, 57(4): 430-437.

18. Korniłłowicz-Kowalska, T. \& Bohacz, J. 2011. Biodegradation of keratin waste: theory and practical aspects. Waste Management, 31: 1689-1701. 
19. Kubota, H., Nambu, Y. \& Endo, T. 1995. Convenient esterification of $\operatorname{poly}(\gamma$-glutamic acid $)$ produced by microorganism with alkyl halides and their thermal properties. Journal of Polymer Science, 33: 85-88.

20. Kunert, J. 1992. Effect of reducing agents on proteolytic and keratinolytic activity of enzymes of Microsporum gypseum. Mycoses, 35: 343-348.

21. Kurosaki, T., Kitahara, T., Fumoto, S., Nishida, K., Nakamura, J., Niidome, T., Kodama, Y., Nakagawa, H., To, H. \& Sasaki, H. 2009. Ternary complexes of pDNA, polyethylenimine, and $\gamma$-polyglutamic acid for gene delivery systems. Biomaterials, 30: 2846-2853.

22. Leonard, C.G., Housewright, R.D. \& Thorne, C.B. 1958. Effects of metallic ions on glutamyl polypeptide synthesis by Bacillus subtilis. Journal of Bacteriology, 76: 499-503.

23. Murao, S., Murakawa, T. \& Omata, S. 1971. Polyglutamic acid fermentation: Culture condition for the production of polyglutamic acid by Bacillus subtilis no. 5E, effects of amino acids and glucose. Part II. Nippon Nogeikagaku Kaishi, 45: 118-123.

24. Ogata, M., Hidari, K.I., Murata, T., Shimada, S., Kozaki, W., Park, E.Y., Suzuki, T. \& Usui, T. 2009. Chemoenzymatic synthesis of sialoglycopolypeptides as glycomimetics to block infection by avian and human influenza viruses. Bioconjugate Chemistry, 20: 538-549.

25. Ogunleye, A., Bhat, A., Irorere, V.U., Hill, D., Williams, C. \& Radecka, I. 2015. Poly- $\gamma$-glutamic acid: production, properties and applications. Microbiology, 161: 1-17.

26. Qiu, Y., Sha, Y., Zhang, Y., Xu, Z., Li, S., Lei, P., Xu, Z., Feng, X. \& Xu, H. 2017. Development of Jerusalem artichoke resource for efficient one-step fermentation of poly-( $\gamma$-glutamic acid) using a novel strain Bacillus amyloliquefaciens NX-2S. Bioresource Technology, 239: 197-203.

27. Ramani, P., Singh, R. \& Gupta, R. 2005. Keratinolytic potential of Bacillus licheniformis RG1: structural and biochemical mechanism of feather degradation. Canadian Journal of Microbiology, 51(3): 191-196.

28. Sangali, S. \& Brandelli, A. 2000. Feather keratin hydrolysis by a Vibrio sp. strain kr2. Journal of Applied Microbiology, 89: 735-743.

29. Steinle, A., Bergander, K. \& Steinbüchel, A. 2009. Metabolic engineering of Saccharomyces cerevisiae for production of novel cyanophycins with an extended range of constituent amino acids. Applied and Environmental Microbiology, 75: 3437-3446.

30. Sung, M.H., Park, C., Kim, C.J., Poo, H., Soda, K. \& Ashiuchi, M. 2005. Natural and edible biopolymer poly- $\gamma$ -glutamic acid: synthesis, production, and applications. Chemical Record, 5: 352-366.

31. Thys, R.C.S., Lucas, F.S., Riffel, A., Heeb, P. \& Brandelli, A. 2004. Characterization of a protease of a feather degrading Microbacterium species. Letters in Applied Microbiology, 39: 181-186.

32. Troy, F.A. 1973. Chemistry and biosynthesis of the $\operatorname{poly}(\gamma-$ D-glutamyl) capsule in Bacillus licheniformis. I. Properties of the membrane mediated biosynthesis reaction. Journal of Biological Chemistry, 248: 306-315.

33. Uotani, K., Hidetoshi, K., Endou, H. \& Tokita, F. 2012. Sialogogue, oral composition and food product containing the same. US Patent 7910089 B2.

34. Vasileva-Tonkova, E., Nustorova, M. \& Gushterova, A. 2007. New protein hydrolysates from collagen wastes used as peptone for bacterial growth. Current Microbiology, 54: 54-57.

35. Wang, Q., Chen, S., Zhang, J., Sun, M., Liu, Z. \& Yu, Z. 2008. Co-producing lipopeptides and poly- $\gamma$-glutamic acid by solid-state fermentation of Bacillus subtilis using soybean and sweet potato residues and its biocontrol and fertilizer synergistic effects. Bioresource Technology, 99: 3318-3323. 